ARTIKEL

E-ISSN: $2615-5028$

\title{
KETIMPANGAN SEBAGAI PENYEBAB KONFLIK: KAJIAN ATAS TEORI SOSIAL KONTEMPORER
}

\author{
Muhamad Zuldin \\ (FISIP UIN SGD Bandung; mubammadzuldin@yahoo.com)
}

\begin{abstract}
This article reviews the relationship between inequality and social conflict in society. This literature review finds that there are at least four schools of thought in contemporary conflict theory that examine the relationship of inequality to conflict. The first is the flow of positive thought which includes the theory of structural conflict. Second is the flow of humanism thinking which consists of symbolic interactions and social construction theory. The third is the school of thought which consists of the thoughts of Jurgen Habermas and Pierre Bourdieu. And the last is a multi-disciplinary school built by Johan Galtung and Anthony Giddens. The four schools of thought develop classical conflict theory, especially Marx's thought that argues that economics is the only factor of conflict in society.
\end{abstract}

Keywords: Theory of conflict, social inequality, critical schools, multidisciplinary approaches

\begin{abstract}
Abstrak
Artikel ini mengkaji ulang hubungan antara ketimpangan dengan konflik sosial di masyarakat. Kajian pustaka ini menemukan bahwa setidaknya ada empat aliran pemikiran dalam teori konflik kontemporer yang mengkaji hubungan ketimpangan dengan konflik. Yang pertama adalah aliran pemikiran positif yang mencakup teori konflik struktural. Kedua adalah aliran pemikiran humanisme yang terdiri dari interaksi simbolik dan teori konstruksi sosial. Yang ketiga adalah mazhab pemikiran yang terdiri dari pemikiran Jurgen Habermas dan Pierre Bourdieu. Dan yang terakhir adalah mazhab multi disiplin ilmu yang dibangun oleh Johan Galtung dan Anthony Giddens. Keempat aliran pemikiran tersebut mengembangkan teori konflik klasik, khususnya pemikiran Marx yang berpendapat ekonomi adalah satu-satunya faktor konflik dalam masyarakat.
\end{abstract}

Kata kunci: Teori konflik, ketimpangan sosial, mazhab kritis, pendekatan multi disiplin

\section{A. PENDAHULUAN}

Konflik merupakan realitas sosial yang sering terjadi di masyarakat. Analisis tentang konflik ini sejalan dengan masa awal perkembangan sosiologi. Teori konflik 
awal atau klasik, yang diwakili oleh Marx, memiliki asumsi yang sederhana tentang masyarakat. Menurutnya, konflik merupakan determinasi oleh faktor ekonomi, khususnya pertentangan antara kaum proletar dengan borjuis. Sejarah merupakan cerita panjang pertentangan kelas antara kaum proletar dan borjuis. Dalam pangangan klasik, konflik diidentikan dengan tindakan destruktif yang menakutkan. Berbeda dengan pandangan klasik, teori konflik kontemporer mengganggap konflik tidak hanya didominasi oleh faktor ekonomi. Konflik dalam pandangan ini merupakan sesuatu yang permanen terjadi di semua lapisan masyarakat yang disebabkan antara lain oleh perebutan kekuasaan, prestise, dan juga kekayaan, yang memang jumlahnya sangat terbatas. Teori konflik kontemporer tidak hanya melihat konflik yang bersifat destruktif, namun juga menganalisis fungsi konflik yang bersifat konstruktif bagi masyarakat. ${ }^{1}$

Ide Marx dikembangkan juga oleh George Sorel. Sorel menganggap konflik sebagai fenomena positif. Dia berpendapat bahwa konflik antar kelas akan mengakibatkan berkuranganya kesatuan sosial di kalangan kelas itu. Oleh karena itu, berkurangnya perjuangan kelas mungkin akan melemahkan dan mengaburkan perbedaan di antara kelas dan dalam keadaan yang ekstrem, kesatuan dan identitas kelas akan terus hilang. Max Gluckman, seorang antropolog Inggris, telah menekankan betapa pentingnya konflik dalam masyarakat primitif. Berdasarkan penelitiannya di Afrika, dia membuat kesimpulan bahwa konflik, dalam hubungan tertentu, dapat mewujudkan kembali kesatuan sosial. ${ }^{2}$

${ }^{1}$ M. Taufiq Rahman, Pengantar Filsafat Sosial, (Bandung: Lekkas, 2018), h. 169.

${ }^{2}$ M. Taufiq Rahman, Glosari Teori Sosial, (Bandung: Ibnu Sina Press, 2011), h. 58. 
Dari penjelasan di atas, tampak bahwa teori konflik telah mengalami revolusi, dari yang bersifat destruktif ke yang lebih bersifat konstruktif. Dengan demikian, semakin modern teori konflik, semakin ia bersifat membangun.

\section{B. TINJAUAN TEORI}

Di bawah ini akan dikemukakan teori sosiologi konflik kontemporer, yang diwakili oleh empat mazhab, yakni mazhab positivis (Ralph Dahrendorf dan Lewis Coser), mazhab humanis (Herbert Blumer dan Peter Berger), mazhab kritis (Bourdieu dan Jurgen Habermas), dan mazhab multidisipliner (Johan Galtung dan Anthony Giddens).

Metodologi yang digunakan oleh penganut mazhab positivistik adalah bebas nilai, universal, ahistoris, analisis makro, dan objektif. Teori yang tercakup adalah konflik struktural: Dialektika konflik wewenang, dan fungsi konflik. Penganut mazhab ini menganalisis dinamika dan pergeseran kelembagaan dari struktur sosial dan konflik perebutan wewenang. Tokohnya adalah Ralph Dahrendorf dan Lewis Coser.

Dahrendorf menyebut teori konfliknya sebagai sosiologi konflik dialektis yang menjelaskan proses terus-menerus distribusi kekuasaan dan wewenang di antara kelompok-kelompok terkoordinasi. Kenyataan sosial, bagi Dahrendorf, merupakan siklus tak berakhir dari adanya konflik wewenang dari berbagai macam tipe kelompok terkoordinasi dari sistem sosial. $^{3}$

Dahrendorf memandang bahwa tidak akan pernah ada masyarakat tanpa kehadiran konflik dan konsensus. Jadi tidak akan ada konflik tanpa kehadiran konsensus sebelumnya. Sebaliknya, konflik dapat menghasilkan konsensus dan

3 Novri Susan. Sosiologi Konflik: Isu-isu konflik kontemporer. (Jakarta: Kencana, 2009). Hlm 52. Cetakan pertama. 


\section{ART IKEL}

integrasi. Tampak bahwa Dahrendorf mengambil posisi di antara keduanya. Untuk kaum fungsionalis, dia menegaskan bahwa sistem sosial dipersatukan oleh kerjasama sukarela atau konsesnsus keduanya. Bagi pendukung teori konflik, dia menegaskan bahwa masyarakat dipersatukan oleh pembatasan yang dipaksakan. Ini berarti bahwa sejumlah posisi dalam masyarakat merupakan kekuasaan dan wewenang yang dilegasikan dari satu pihak atas pihak lainnya. Fakta tentang kehidupan sosial ini menggiring Dahrendorf kepada tesis utamanya bahwa pendistribusian wewenang merupakan faktor penentu dari konflik-konflik sosial yang sistematis. ${ }^{4}$

Dalam membangun tesisnya, Dahrendorf menggunakan teori perjuangaan kelas Marxian guna membangun teori kelas dan pertentangan kelas dalam menganalisis masyarakat industri modern. Menurutnya kelas tidak berarti pemilikan sarana-sarana produksi (seperti yang dilakukan oleh Marx) tetapi lebih pada pemilikan kekuasaan, yang mencakup hak absah untuk menguasai orang lain. Perjuangan kelas dalam masyarakat modern, baik dalam perekonomian kapitalis maupun komunis, dalam pemerintahan bebas dan otoriter, berada di seputar pengendalian kekuasaan. ${ }^{5}$

Tesis Dahrendorf ini merupakan kritik sekaligus penyempurnaan terhadap pemikiran Marx yang cenderung hanya menekankan aspek ekonomi sebagai faktor dominan. Menurut Marx konflik terjadi karena ada ketimpangan pemilikan materi oleh masyarakat yang disebabkan oleh adanya ekploitasi berlebihan dari kelompok pemilik modal (kapitalis) terhadap kelompok yang tidak memiliki (lumpen proletar), sehingga kesenjangan antara yang memiliki dan yang tidak memiliki semakin lebar. Faktor materi

4 Judistira K Garna dalam Sunarta. Integrasi dan Konflik: Kedudukan Politik Jawara dan Ulama dalam Budaya Politik Lokal (Bandung: PPS Unpad Bandung, 1997) hlm 25. Disertasi.

5 Margaret M. Poloma. Sosiologi Kontemporer. (Jakarta: Raja Grafindo Persada, 2003) hlm 144. Cetakan ke-5. Diterjemahkan oleh tim penerjemah Yosogama dari judul asli Contemporary Socilogical Theory. 
inilah menurut Marx, yang menjadi sumber dan penyebab kecemburuan sosial. Dahrendorf memang mengakui bahwa materi merupakan salah satu elemen penyebab konflik, tetapi menurutnya tidaklah sesederhana itu. Bagi Dahrendorf, penyebab ketimpangan dalam masyarakat dapat ditelusuri dengan konsep kekuasaan (power) dan wewenang (authority) yang dimiliki masyarakat. Perbedaan dalam posisi, kekuasaan, dan wewenang yang tidak merata akan berdampak pada perbedaan dan perolehan kepemilikan materi, yang mengakibatkan terjadinnya kesenjangan. Jadi sumber utama atau faktor dominan konflik dalam masyarakat adalah tidak terdistribusinya secara merata kekuasaan dan wewenang dalam masyarakat.

Kekuasaan (power) dalam masyarakat modern dan industrial bisa diterjemahkan sebagai wewenang (authority). Menurut Dahrendorf, wewenang adalah:

(1) Relasi wewenang yaitu selalu relasi-relasi antar super subordinasi; (2) di mana ada relasi-relasi wewenang, kelompok-kelompok superordinasi selalu diharapkan mengontrol perilaku kelompok-kelompok subordinasi melalui permintaan dan perintah serta peringatan dan larangan; (3) berbagai harapan tertanam relatif permanen dalam posisi sosial dari pada karakter individu; (4) dengan keberadaan fakta ini atau kekuasaan superordinasi, mereka selalu melibatkan spesifikasi subjek-subjek perorangan untuk mengontrol dan; (5) spesifikasi dari ruang sosial yang kontrol mungkin dilakukan; dan (5) wewenang menjadi hubungan terlegitimasi, tanpa protes dengan perintahperintah otoritatif dapat diberi sanksi; sesungguhnya ini merupakan fungsi sebenarnya dari sistem legal untuk mendukung pemberlakuan wewenang yang memiliki legitimasi. ${ }^{6}$

Kekuasaan dan otoritas merupakan sumber-sumber yang menakutkan dan mereka yang memegangnya memiliki kepentingan untuk mempertahan status quo. Dahrendorf mengatakan hal ini merupakan kepentingan objektif yang terbentuk dalam peran-peran itu sendiri, bersamaan dengan kepentingan atau fungsi dari semua peran dalam mempertahankan organisasi itu sebagai keseluruhan. Dunia sosial karenanya

${ }^{6}$ Ralf Darendorf. Class and Class Conflict in Industrial Society (California: Stanford University Press, 1959) .hlm 166-167. 


\section{ART IKEL}

distruktur ke dalam kelompok-kelompok sosial yang secara potensial mengandung konflik. Inilah yang ia sebut dengan quasi-group. ${ }^{7}$

Ketimpangan dan konflik itu tidak terjadi hanya pada masyarakat kapitalis dan proletar, tetapi juga pada semua bentuk masyarakat, seperti keluarga, organisasi, militer, negara atau dalam semua aspek kehidupan seperti ekonomi, sosial, budaya, agama, hukum, dan keamanan. Jadi konflik sosial, menurut Dahrendorf, meliputi aspek yang sangat luas, tidak seperti yang dikatakan Marx yang hanya terbatas pada ekonomi dan bersifat materi belaka. ${ }^{8}$

Dahrendorf juga berpandangan bahwa tidak setiap konflik mengarahkan pada perpecahan, tetapi juga mengarah pada perubahan sosial dan perkembangan, seperti dinyatakan oleh George Ritzer:

Briefly, Dabrendorf argued than once conflict groups emerge, they engage in actions that lead to changes in social strructure. When the conflict is intense, the changes that accur are radical. When it is accompanied by violence, structural change will be sudden. Whatever the nature of conflict, sociologist must be attuned to the relationship between conflict and change as well as as that between conflict and the status quo.'

Pemikiran Dahrendorf telah membuka wawasan yang lebih luas dalam mengkaji setiap fenomena konflik sosial yang tidak terbatas pada determinasi ekonomi saja atau pemilik modal dengan memilili modal. Teori ini, disamping untuk menganalisis konflik struktural yang disebabkan faktor kekuasaan, tetapi juga bisa digunakan untuk menganalisis derivasi dari kekuasaan seperti konflik yang bersumber dari agama dan budaya.

7 Ian Craib. Teori-Teori Sosial Modern dari Parsons sampai Habermas hlm 98

8 Yohanes Bahari. Resolusi Konflik Berbasis Pranata Adat Pamakang dan Pati Nyawa pada Masyarakat Dayak Kanayatn di Kalimantan Barat (Bandung, Program PPS Unpad, 2005) hlm 33-34. Disertasi.

9 George Ritzer. Sociological Theory. (Singapore: McGraw-Hill, 1992) hlm 266. Third Edition. 
Mengenai fungsi konflik, sebenarnya telah dibahas oleh George Simmel. Namun demikian, karya Simmel ini telah diperluas oleh Lewis Coser yang menyatakan bahwa konflik dapat berfungsi memperkokoh kelompok sosial yang kurang terstruktur. Di dalam masyarakat yang kurang terintegrasi, konflik dapat berfungsi mengembalikan integrasi sosial. Menurut Coser, konflik dapat berfungsi sebagai berikut: "1) Conflict with one group may serve to produce coheesion by leading to a series of alliances with other groups. 2) Within society, conflict can bring some ordinarily isolated individuals into active role. 3) Conflict also serve a communication function."'10

Lebih jauh lagi, proposisi Simmel dan Coser tentang konflik dan integrasi diungkap oleh Saifudin sebagai berikut:

Proposisi Simmel tentang konflik dan integrasi telah dirumuskan dan dipertajam oleh Coser, antara lain: 1) konflik berfungsi menegakkan dan mempertahanan identitas dan batas-batas kelompok sosial masyarakat, 2) konflik tidak selalu bersifat disfungsional dalam kontek hubungan di mana konflik tersebut terjadi, sebaliknya seringkali konflik diperlukan untuk mempertahankan hubungan mereka, 3) Dilihat konflik sebagai sarana dan sebagai tujuan maka terdapat dua macam konnflik yaitu: konflik realistis dan konflik non realistis, 4) konflik yang lebih radikal dapat terjadi dalam perkumpulan dan organisasi oposisi yang mempertajam konflik, 4) konflik dapat melenyapkan unsusr-unsur yang memecah belah dan menegakkan kembali persatuan, 5) konflik dapat melenyapkan unsusr-unsur yang memecah belah dan menegakkan kembali persatuan, 6) konflik suatu kelompok dengan kelompok-kelompok yang lain menghasilkan mobilisasi energi para anggota kelompok yang bersangkutan, sehingga kohesi kelompok ditingkatkan, 7) ada tiga aspek struktur kelompok yang harus diperhatikan yaitu; ukuran relatif, kelompok, tingkat keterlibatan anggota-anggotanya dan situasi sosial, 8) suatu konflik di mana pelakunya merasa bahwa mereka semata-mata wakil kolektif atau cenderung lebih radikal karena kesadarn bahwa perjuangan mereka berlandaskan pada ideologi tertentu, 9) konflik dapat menciptakan jenis-jenis interaksi yang baru diantara pihak-pihak yang bertentangan yang sebelumnya tidak ada, 10) konflik dapat mempersatukan orang-orang atau kelompok yang tadinya tidak saling berhubungan. ${ }^{11}$

${ }^{10}$ Lewis Coser. The function of social conflict. (New York: Free Press, 1956) dalam Sunarta. Integrasi dan Konflik: Kedudukan Politik Jawara dan Ulama dalam Budaya Politik Lokal. Hlm 26-27. Lihat juga George Ritzer. Sociological Theory. Hlm 268-269.

11 Ahmad Fedyani Saifuddin, Konflik dan Integrasi: Perbedaan Faham dalam Agama Islam. (Jakarta: Rajawali, 1986) hlm 44 
Lebih lanjut Coser berasumsi bahwa konflik akan fungsional bagi sistem sosial sebagai berikut: menstabilkan hubungan, mengfungsikan kembali keberadaan keseimbangan, menambah munculnya norma-norma baru, menyediakan mekanisme bagi penyesuaian diri yang terus-menerus dari keseimbangan kekuasaan, mengembangkan koalisi dan asosiasi baru, menurunkan isolasi sosial, dan menyumbangkan untuk pemeliharaan garis batas kelompok. Secara umum, konflik akan menghasilkan keadaan yang lebih stabil, fleksibel, dan sistem sosial yang lebih terpadu. $^{12}$

Coser membagi konflik menjadi dua: konflik eksternal (external conflict) dan konflik internal(internal conflict). Konflik ekternal mampu menciptakan dan memperkuat identitas kelompok. Dia menyatakan: "...konflik membuat batasanbatasan di antara dua kelompok dalam sistem sosial dengan memperkuat kesadaran dan kesadaran kembali atas keterpisahan, sehingga menciptakan kesadaran identitas kelompok dalam sistem." ${ }^{\prime 3}$ Sedangkan fungsi konflik internal adalah memberi fungsi positif terhadap kelompok identitas mengenai adanya kesalahan perilaku. Selain itu, konflik internal merupakan mekanisme bertahan dari eksistensi suatu kelompok.

Coser juga membedakan dua tipe dasar konflik, yaitu konflik realistis dan konflik non realistis. Konflik realistik memiliki sumber yang kongkrit atau bersifat material, seperti perebutan sumber ekonomi atau wilayah. Jika mereka telah memperoleh sumber rebutan itu, dan bila dapat diperleh tanpa perkelahian, maka konflik akan segera diatasi dengan baik. Konflik non realistis didoroang keinginan yang tidak

12 Graham C. Kinloch. Perkembangan dan Paradigma Utama Teori Sosiologi. (Bandung: Pustaka Setia, 2005) hlm 228. Cetakan Pertama. Editor: Dadang Kahmad. Diterjemahkan dari Sociological Theory: Its Development and Major Paradigm.

13 Lewis Coser. The function of Social Conflict. Hlm 37 dalam Novri Susan hlm 53. 
rasional dan cenderung bersifat ideologis, seperti konflik antar agama, antar etnis, dan konflik antar kepercayaan lainnya. Konflik adalah tujuan itu sendiri, baik diizinkan atau tidak. Konflik non realistis merupakan suatu cara menururnkan ketegangan atau mempertegas identitas satu kelompok, dan cara ini mewujudkan bentuk-bentuk kekejian yang sesungguhnya turun dari sumber-sumer lain. Antara konflik pertama dan kedua, konflik non realistis cenderung sulit untuk menemukan resolusi konflik, konsensus dan perdamaian tidak akan mudah diperoleh. Menurut Coser, sangat memungkinkan bahwa konflik melahirkan kedua tipe ini sekaligus sehingga menghasilkan situasi konflik yang lebih komplek. ${ }^{14}$

Menurut Wallace dan Wolf, fungsi positif konflik internal terhadap kelompok bisa berlaku tatkala konflik tidak menyertakan nilai-nilai dan prinsip dasar. Hal ini terkait dengan tipe kelompok menurut Coser yakni bahwa konflik yang menyertakan nilai-nilai dan prinsip dasar biasanya bersifat nonrealistis. Melalui pengelolaan konflik yang baik, sebagai safety valve, maka sistem akan berjalan dengan stabil dan berperan mengintegrasikan struktur sosial. ${ }^{15}$

Teori konflik Coser yang membahas konflik internal dan konflik ekternal dan konflik realistis dan konflik non realistik sangat relevan dipakai untuk menganalisis konflik kelompok keagamaan. Demikian pula dengan konsep savety valve yang

\footnotetext{
14 Ibid. hlm 54-55. Bandingkan dengan Nasikun yang membagi dua macam tingkatan konflik: Konflik ideologis dan konflik politis. Konflik ideologis terwujud dalam bentuk konflik antar sistem nilai yang dianut dan menjadi ideologi dari berbagai kesatuan sosial. Konflik ini mudah disimak di dalam hubungan perbedaan agama dan keyakinan, dan konflik antar suku bangsa. Konflik bersifat politis terjadi dalam bentuk pertentangan di dalam pembagian status kekuasaan dan sumber-sumber ekonomi yang terbatas di masyarakat. Nasikun. Sistem Sosial Indonesia. (Jakarta: CV Rajawali, 1992). Hlm 63. Cetakan ketujuh. 15 Wallace \& Wolf .Reading in Contemporary Sociological Theory from Modernity to Post Modernity. (New Jersey: Printice Hall. 1995) hlm 159
} 
dikemukan oleh Simmel dan ditegaskan kembali oleh Coser yang berfungsi sebagai jalan tengah solusi konflik sangat berguna untuk menganalisis resolusi konflik.

\section{HASIL DAN PEMBAHASAN}

Teori sosiologi humanis berkembang sebagai respons terhadap analisis makro fungsionalisme struktural. Teori ini berguna untuk menganalisis konflik masyarakat, konflik mikro atau konflik antar individu dan individu terhadap kelompok. Teori-teori yang berada dalam mazhab ini teori interaksi simbolik dan teori konstruksi sosial.

Tokoh awal teori interaksinisme simbolik adalah Herbert Mead, yang menggabungkan filsafat pragmatisme dan behaviorisme psikologis. Karyanya yang sangat penting adalah Mind, Self, and Society. ${ }^{16}$ Mind atau pikiran didefinisikan Mead sebagai proses percakapan seseorang dengan diri sendiri, tidak ditemukan di dalam diri individu; pikiran adalah fenomena sosial. Pikiran muncul dan berkembang dalam proses sosial dan merupakan bagian integral dari proses sosial. Proses sosial mendahului pikiran, proses sosial bukanlah produk dari pikiran. Karakteristik istimewa dari pikiran adalah kemampuan individu untuk memunculkan dalam dirinya sendiri tidak hanya satu respon saja, tetapi juga respon komunitas secara keseluruhan. Mead juga melihat pikiran secara pragmatis, yakni pikiran melibatkan proses berpikir yang mengarah pada penyelesaian masalah dan memungkinkan orang melakukan sesuatu lebih efektif dalam kehidupan. ${ }^{17}$

16 George Ritzer dan Douglas J. Goodman. Teori Sosial Modern .Jakarta: Kencana, 2004) hlm 271. Edisi pertama. Diterjemahkan oleh Alimandan dari buku aslinya Modern Sociological Theory, Sixth Edition.

17 Ibid. hlm 280 
Selfatau diri adalah kemampuan menerima diri sendiri sebagai suatu objek. Diri mensyaratkan proses sosial: komunikasi antar manusia. Lebih lanjut Mead mendefinisikan tentang "diri":

Diri adalah di mana orang memberi tanggapan terhadap apa yang ia tujukan kepada orang lain dan di mana tanggapannya sendiri menjadi bagian dari tindakannya, di mana ia tidak hanya mendengar dirinya sendiri, tetapi juga merespon dirinya sendiri, berbicara dan menjawab dirinya sendiri sebagaimana orang lain menjawab pada dirinya, sehingga kita mempunyai perilaku di mana individu menjadi objek untuk dirinya sendiri.

Karena itu diri adalah aspek lain dari proses sosial menyeluruh di mana individu adalah bagiannya. Ahirnya Mead mengatakan, " Hanya dengan mengambil peran orang lainlah kita mampu kembali kepada diri kita sendiri. ${ }^{18}$

Diri, menurut Mead, pada dasarnya merupakan proses sosial yang berlangsung dua fase yang dapat dibedakan, yaitu "I" dam "Me". "I' adalah tanggapan spontan terhadap orang lain. "Me" merupakan penerimaan atas orang lain yang digeneralisir. Kontrol sosial terbentuk karena keunggulan ekpresi "Me" di atas ekpresi "I".

Society atau masyarakat berarti proses sosial tanpa henti yang mendahului pikiran dan diri. Menurut Mead, masyarakat penting perannya dalam membentuk pikiran dan diri. Masyarakat mencerminkan sekumpulan tanggapan terorganisisr yang diambil alih oleh individun dalam bentuk "me". Pada tingkat kemasyarakatan yang lebih khusus, Mead mendefinisikan pranata sosial sebagai "tanggapan bersama dalam komunitas" atau" kebiasaan hidup berkomunitas". Menurutnya, ada pranata sosial yang bersifat menindas, stereotif, dan ultrakonservatif, seperti lembaga keagamaan. ${ }^{19}$

18 Ibid, hlm 281-282

19 Ibid. hlm 287-288 
Istilah interaksi simbolik merupakan sumbangan orisinil Herbert Blumer melalui artikelnya Man and Society (1969). Ia menyebutkan tujuh prinsip dasar teori ini, sebagai berikut:

a. Tak seperti binatang manusia dibekali kemampuan untuk berpikir.

b. Kemampuan berpikir dibentuk oleh interaksi sosial.

c. Dalam interaksi sosial manusia mempelajari arti dan simbol yang memungkinkan mempelajari arti dan simbol yang mereka menggunakan kemampuan berpikir mereka yang bersifat khusus.

d. Makna dan simbol memungkinkan manusia melanjutkan tindakan khusus dan berinteraksi.

e. Manusia mampu mengubah arti dan simbol yang mereka gunakan dalam tindakan dan interaksi berdasarkan penafsiran mereka terhadap situasi.

f. Manusia mampu membuat kebijakan modifikasi dan perubahan, sebagian karena kemampuan mereka berinteraksi dengan diri mereka sendiri, yang memungkinkan mereka menguji serangkaian peluang tindakan, menilai keuntungan dan kerugian mereka, dan memilih salah satu diantara serangkaian peluang tindakan itu.

g. Pola tindakan dan interaksi yang saling berkaitan akan membentuk kelompok dan masyarakat. ${ }^{20}$

Menurut Poloma, premis teori interaksi simbolik Blumer bertumpu pada:

1. Manusia bertindak terhadap sesuatu berdasarkan makna-makna yang ada pada sesuatu itu bagi mereka.

2. Makna tersebut berasal dan interaksi sosial seseorang dengan orang lain.

20 Ibid. hlm 289 
3. Makna-makna tersebut disempurnakan di saat proses sosial makna. ${ }^{21}$

Jadi, tindakan-tindakan bersama dalam masyarakat adalah disebabkan oleh adanya interaksi simbolis. Melalui simbol-simbol yang telah mereka maknai bersama tersebut disampaikan pada pihak lain. Simbol yang umum digunakan adalah bahasa, baik bahasa lisan, tulisan, atau isyarat.

Sosiologi konflik menggunakan analisis interaksi simbolik untuk melihat berbagai fenomena konflik pada skala mikro dan lingkungan yang lebih spesifik. Simbol bisa dimaknai secara variatif oleh masing-masing aktor dalam interaksi sosial. Makna negatif dalam bentuk kebencian akan mengakibatkan prasangka (prejudice) dan tindakan permusuhan (bostile feeling). ${ }^{22}$

Teori interaksi simbolik ini dapat juga digunakan untuk menganalisis konfllik agama. Beberapa simbol agama yang dipahami secara berbeda dari suatu kelompok masyarakat dengan kelompok lainnya tidak jarang menimbulkan konflik. Untuk menunjukkan rasa permusuhan (bostile feeling) satu kelompok dengan kelompok lain, di samping melakukan tindak kekerasan, juga dilakukan dengan simbol-simbol yang bersifat mendiskreditkan kelompok lawan.

Teori lainnya dalam mazhab humanisme adalah teori konstruksi sosial. Teori ini dikembangkan oleh Peter L.Berger dan Luckman (1966) dalam The Social Construction of Reality. Konstruksi sosial merupakan kajian yang berkembang dari

21 Margaret M. Poloma. Sosiologi Kontemporer. Hlm 258.

22 Novri Susan. Sosiologi Konflik: Isu-isu konflik kontemporer. Hlm 63. 
sosiologi pengetahuan yang melihat konflik sebagai manifestasi sosial dari dialektika sosial.

Berger memahami dunia kehidupan selalu dalam proses dialektis, antara individu (self) dengan dunia sosial. Proses dialektik ini mencakup tiga unsur yaitu ekternalisasi, objektivasi, dan internalisasi. Dalam sejarah umat manusia, ekternalisasi, objektivasi, dan internalisasi merupakan tiga proses yang berjalan terus menerus. Masyarakat adalah sebuah produk yang tidak pernah berakhir.

Fase ekternalisasi dan objektivasi merupakan pembentukan masyarakat yang disebut sebagai sosialisasi primer, yaitu saat seseorang berusaha mendapatkan dan membangun tempatnya dalam masyarakat. Kedua fase ini membuat orang memandang masyarakat sebagai realitas objektif atau man in society. Tahap internalisasi, yang lebih lanjut agar pranata ini dapat dipertahankan, harus ada pembenaran terhadap pranata tersebut, tetapi pembenaran itu dibuat juga oleh manusia sendiri melalui proses legitimasi yang disebut dengan objektivasi sekunder. Pranata sosial merupakan hal yang objektif dan independen. Kenyataan sosial merupakan suatu konstruksi sosial buatan masyarakat sendiri dalam perjalanan sejarahnya dari masa silam, ke masa kini dan menuju masa depan. Konstruksi sosial in pada gilirannya bersifat plural, relatif, dan dinamis. Dalam arti, kelompok-kelompok sosial dalam masyarakat memiliki kehendak dalam membangun realitas sosial, dan setiap kehendak tersebut harus berhadapan satu sama lain dan saling mendominasi. Oleh karenanya, konflik di antara kelompokkelompok sosial sering muncul. ${ }^{23}$

23 Ibid. hlm 66-67. 


\section{ART IKEL}

\section{E-ISSN: $2615-5028$}

Paul Lederach menjelaskan bagaimana konflik dalam perspektif konstruksi sosial terjadi. Ada tujuh asumsi yang ia kemukakan, yaitu:

1. Konflik sosial dipahami sebagai hal yang alamiah.

2. Konflik sosial dipahami sebagai kejadian konstruktif kebudayaan secara sosial. Konflik tidak hanya terjadi pada seseorang, tetapi orang merupakan peserta aktif dalam menciptakan situasi dan interaksi yang mereka ambil pengalaman sebagai konflik.

3. Konflik muncul melalui proses interaktif yang melandaskan pada pencarian dan penciptaan makna bersama.

4. Proses interaktif disempurnakan melalui persepsi manusia, interpretasi, ekpresi, dan niatan-niatan, yang kesemuanya tumbuh dan kembali pada ke kesadaran umum (common sense) mereka.

5. Pemaknaan muncul sebagaimana manusia meletakkan diri mereka sendiri dan sosial seperti situasi, kejadian, dan tindakan di dalam pengetahuan mereka.

6. Kebudayaan berakar di dalam pengetahuan bersama dan skema-skema digunakan oleh sekelompok oran guntuk merasakan, menafairkan, mengekppresikan, dan merespons kenyataan sosial di sekitar merea.

7. Pemahaman hubungan konflik sosialtidak hanya satu pertanyaan sensitif dari kesadaran, tetapi lebih jauh petualangnan yang dalam arti penemuan dan penggalian arkeologis dari pengetahuan umum dari sekelompok orang. ${ }^{24}$

Teori konstruksi realitas ini dapat digunakan untuk menganalisis konflik agama. Setiap kelompok keagamaan akan berusaha mengkonstruksi realitas sosial

24 Ibid. hlm 67-68. 
seperti kepercayaan yang mereka yakini, bahkan seringkali melakukan ekspansi. Agama sebagai lembaga sosial, menurut Berger, menjadi sumber pembenaran yang paling efektif. Ketika berhadapan dengan konstruksi realitas kelompok-kelompok lain yang berbeda penafsiran dan pandangan, konflik sosial akan muncul.

Sedangkan Mazhab Kritis memiliki pandangan bahwa sosiolog mempunyai kewajiban moral mengajak dan melakukan kritik terhadap dominasi penguasa terhadap masyarakat dalam struktur sosial. Oleh karenanya, teori kritis adalah merupakan emansipasi yang berusaha membebaskan masyarakat dari kekejaman struktur sosial yang menindas masyarakat oleh sekelompok penguasa. Kelompok ini diwakili oleh Jurgen Habermas dan Pierre Bourdieu. Mereka semuanya dipengaruhi oleh Karl Marx.

Habermas mengakui bahwa konflik adalah sesuatu yang inheren dalam sistem masyarakat. Hal ini tidak terlepas dari hubungan kekuasaan dalam sistem sosial dan sifat kekuasaan yang mendominasi. Sosiologi konflik mazhab kritis Habermas menganalisis kondisi dari dominasi struktural. Kelompok penguasa mengarahkan berbagai bentuk kebijakan pada orang lain di luar wewenang dan kekuasaannya. Kondisi ini merupakan bentuk dominasi. Habermas melihat komunikasi yang dihasilkan dari kondisi ini selalu memuat kepentingan penguasa untuk menundukkan. Inilah yang disebut Habermas dengan komunikasi intrumrntal. Komunikasi intrumental hanya memberi peluang pada pemilik kekuasaan, dan tidak akan menciptakan kesepahaman (mutual understanding). ${ }^{25}$

25 Jurgen Habermas. On The Pragmatics of Communication. (Massachusetts: The MIT Press, 1998) hlm 2 dalam Novri Susan. Sosiologi Konflik: Isu-isu konflik kontemporer. Hlm 69. 
Dalam masyarakat modern, kesadaran intrumental ini berakar pada rasionalisme. Habermas dalam The Theory of Communicative Action memperlihatkan bagaimana kesadaran intrumental menciptakan model komunikasi yang sifatnya mengusai. Birokrasi modern adalah struktur negara yang menggunakan kesadarn dan komunikasi interumetal. Kondisi inilah yang menyebabkan ketertindasan masayrakat dalam bentuk ketidakmampuan mengeluarkan pendapt mengenai keinginan dan harapan mereka. Negara dan birokrasinya menutup ruang berpendapat masyarakat (public sphere) melalui kontrol keamanan dan kebijakan-kebijakan lainnya. Terkuncinya ruang publik bisa mengakibatkan kekesalan, frustasi, dan bentuk kekerasan dalam perlawanan politik. Untuk itu Habermas mengajukan kondisi ini atau komunikasi interumental diubah menjadi komunikasi intersubjektif. Komunikasi intersubjektif ini membuka ruang-ruang dialog yang bebas dari dominasi penguasa. Para penguasa yang melegitimasi wewenang dan kebijakan harus bersedia menggunakan komunikasi yang setara dan terbuka sehingga dapat menghindari konflik antara pengambil keputusan dan masyarakat biasa.

Teori Habermas ini juga bisa digunakan untuk menganalisis konflik antar kelompok agama dan kelompok agama dengan pemerintah. Seringkali dalam memutuskan kebijakan, khususnya tentang keagamaan, pemerintah tidak melibatkan semua pihak. Keputusan yang diambil kadang diabaikan bahkan terjadi penolakan baik melalui kekerasan maupun proses hukum.

Tokoh teori sosiologi kritis lainnya adalah Pierre Bourdieu yang berasal dari Perancis. Ia menolak determinisme kelas Marxisme yang melihat masyarakat sebagai hubungan kelas dan ditentukan oleh kepentingan materi. Ia menggunakan istilah field 
(lapangan) yang berarti arena sosial orang-orang yang menciptakan berbagai manuver, menciptakan berbagai strategi dan berjuang demi sumberdaya yang diinginkan.

Menurut Bourdieu, posisi tertentu memiliki kekuasaan yang lebih dari posisi yang ada dibawahnya. Sumber kekuasaan adalah modal (capital), yang terbagi menjadi tiga: Modal ekonomi (economic capita), modal sosial (social capital), dan modal budaya (cultural capital). Modal ekonomi merupakan sumber kekuasaan yang bersifat materi. Semakin banyak materi yang dimiliki, semakin besar kekuasannya. Modal sosial merupakan sumber kekuasaan yang diperoleh melalui jaringan (network) dan pengaruh sosial. Modal budaya merujuk pada seseorang merasakan dan mempersepsikan sesuatu, baik atau buruk, boleh atau tidak.

Legitimasi modal budaya menjadi penting bagi proses reproduksi dominasi. Legitimasi inilah yang sering melahirkan kekerasan simbolik, yaitu kekerasan melalui praktik bahasa. Reproduksi dari sistem reproduksi melalui modal budaya bisa dipahami melalui praktek habitus. Dalam Language and Symbolic Power (1992), Bourdieu memperlihatkan bagaimana habitus muncul melalui praktek kompetensi bahasa dalam setiap field. Kompetisi bahasa didefinisikan sebagai wewenang untuk mengucapkan sesuatu. Misalnya pembicaraan tentang sesat tidaknya suatu aliran merupakan kompetensi ulama mayoritas ketimbang minoritas. Kompetensi inilah yang kemudian mendapat perlawan dari aliran yang dianggap sesat.

Sebenarnya teori Bourdieu ini pada awalnya digunakan untuk menganalisis dominasi kelas melalui sistem pendidikan di Perancis. Namun demikian, teori ini juga dapat digunakan untuk menganalisis konflik-konflik kelompok keagamaan yang penuh 


\section{ART IKEL}

dengan simbol-simbol bahasa yang menunjukkan kekuasaan suatu kelompok dengan kelompok lainnya.

Kemudian muncul pula Mazhab Multidisipliner. Mazhab ini dipelopori oleh Johan Galtung dan Anthony Giddens. Mazhab multidisipliner ini dalam menganalisis konflik tidak hanya menggunakan satu teori atau pendekatan, tetapi menggunakan berbagai macam teori atau disiplin ilmu berdasarkan kebutuhan analisis.

Galtung menjelaskan konflik dengan konsep intervensi konflik. Intervensi harus netral. Ini adalah ciri dari mazhab positivistik, namun Galtung menyarankan perubahan-perubahan dalam menciptakan hubungan konflik yang konstruktif. Pendekatan ini dikenal dengan trancend approach.

Dalam menjelaskan analisis konflik, Galtung menggunakan segitiga konflik. Ia memperlihatkan individu, kelompok dan organisasi membawa angka kepentingan masing-masing. Kepentingan itu bisa berwujud dalam bentuk ekonomi dan politik. Dua kelompok sosial dengan kepentingan ekonomis dalam satu lingkungan yang sama, masing-masing akan menciptakan persepsi terhadap kepentingan kelompok di luarnya. Proses ini akan membawa pada bentuk prilaku-prilaku tertentu yang menciptakan kontradiksi dan situasi ketegangan. Segitiga konflik ini merupakan analisis hubungan sebab akibat atau interaksi yang memungkinkan terjadinya konflik sosial. Tiga segitiga tersebut terdiri dari sikap, perilaku, dan kontradiksi. Sikap adalah persepsi anggota etnis tentang isu-isu tertentu yang berkaitan dengan kelompok laian. Perilaku dapat berupa kerjasama, persaingan atau konflik. Kontradiksi adalah kemunculan situasi yang melibatkan problem sikap dan perilaku sebagai proses. Hal ini dapat digambarkan sebagai berikut: 


\section{Gambar 1. Segitiga Konflik Galtung}

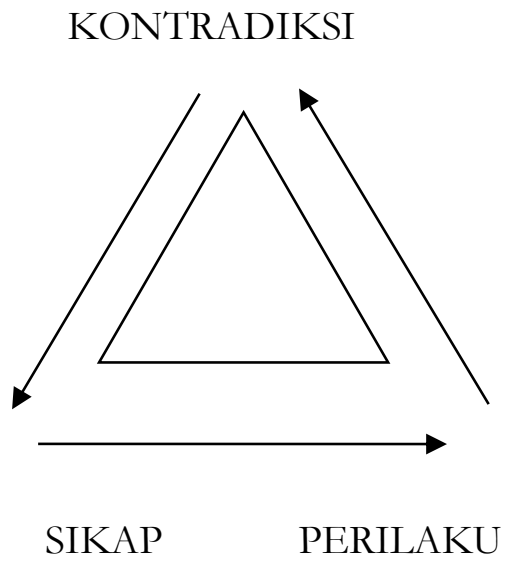

Galtung dalam teori kekerasannya menyatakan bahwa konflik kekerasan dapat

dibedakan dalam tiga jenis yakni:

(1) Kekerasan kultural ; (2) kekerasan struktural ; dan (3) kekerasan langsung. Kekerasan kultural adalah kekerasan yang melegitimasi terjadinya kekerasan struktural dan kekerasan langsung serta menyebabkan tindakan dianggap wajar saja atau dapat diterima oleh masyarakat. Kekerasan struktural adalah kekerasan yang berbentuk eksploitasi sistematis disertai mekanisme yang menghalangi terbentuknya kesadaran serta menghambat kehadiran lembaga-lembaga yang dapat menentang eksploitasi dan penindasan. Kekerasan jenis ini lebih tersembunyi seperti: ketidakadilan, kebijakan yang menindas dan perundang-undangan yang diskriminatif. Kekerasan struktural ini termanifestasi dalam bentuk ketimpangan kekuasaan ekonomi yang menyebabkan ketimpangan kesejahteraan hidup. Kekerasan langsung adalah kekerasan yang terlihat secara langsung dalam bentuk kejadian atau perbuatan, sehingga kekerasan jenis ini sangat mudah diidentifikasi karena merupakan manifestasi dari kekerasan kultural dan struktural. ${ }^{26}$

\footnotetext{
${ }^{26}$ Johan Galtung Peace by Peaceful Means: Peace and conflict Development and civilization.(London: IPRIO, 1996) dalam Yohanes Bahari. Hlm 51-52. Lihat pula Johan Galtung. Kekerasan Budaya dalam Thomas Santoso (ed) Teori-Teori Kekerasan (Jakarta: Ghalia, 2002) hlm 183-184. Jamil Salmi membagi empat jenis kekerasan: Kekerasan langsung, kekerasan tidak langsung, kekerasan repsesif, dan kekerasan alienatif. Kekerasan langsung merujuk pada tindakan yang menyerang fisik atau psikologis seseorang secara langsung, seperti pemusnahan etnis, penganiayaan, dan pengusiran paksa terhadap masyarakat. Kekerasan tidak langsung adalah tindakan yang membahayakan manusia, bahkan kadang-kadang ancaman kematian, tetapi tidak melibatkan hubungan langsung antara korban dan pihak yang bertanggung jawab atas tindakan tersebut, termasuk kekerasan yang dibiarkan dan dimediasi. Kekerasan represif berkaitan dengan pencabutan hak-hak dasar selain hak untuk bertahan hidup dan hak untuk dilindungi darikesakitan atau penderitaan. Kekerasan alienatif merujuk pada hak-hak individu yang lebih tinggi, misalnya hak pertumbuhan kejiwaan (emosi), hak budaya dan hak intelektual. Jamil Salmi. Violence and Democratic Society: Hooligansime dan Masyarakat Demokrasi. (Yogyakarta: 2005, Nuansa Aksara) hlm 32-
} 
Galtung menggambarkan ketiga jenis tipe tersebut sebagai citra segitiga kekerasan yang pada lapisan bagian bawah terdapat arus stabil melalui waktu kekerasan kultural, yaitu substrata yang mengalirkan semacam nutrient (zat gizi) bagi kedua jenis kekerasan lainnya, Dalam strata selanjutnya, terletak irama kekerasan struktural. Pada bagian atas, yang terlihat oleh mata telanjang, adalah strata kekerasan langsung dengan record kekejaman langsung yang dilakukan oleh manusia terhadap manusia lainnya dan terhadap bentuk-bentuk lain atau kehidupan dan alam pada umumnya. Cara kerja ketiga bentuk kekerasan tersebut berdasarkan arus kausal yang berantai dan satu titik ke titik lainnya di mana siklus-siklus yang menghubungkan ketiga jenis kekerasan tersebut bisa bermula dari titik yang mana saja, dari kekerasan kultural melalui kekerasan struktural sampai kekerasan langsung atau sebaliknya. ${ }^{27}$

\section{Gambar 2. Proses Terjadinya Konflik Kekerasan menurut Galtung}

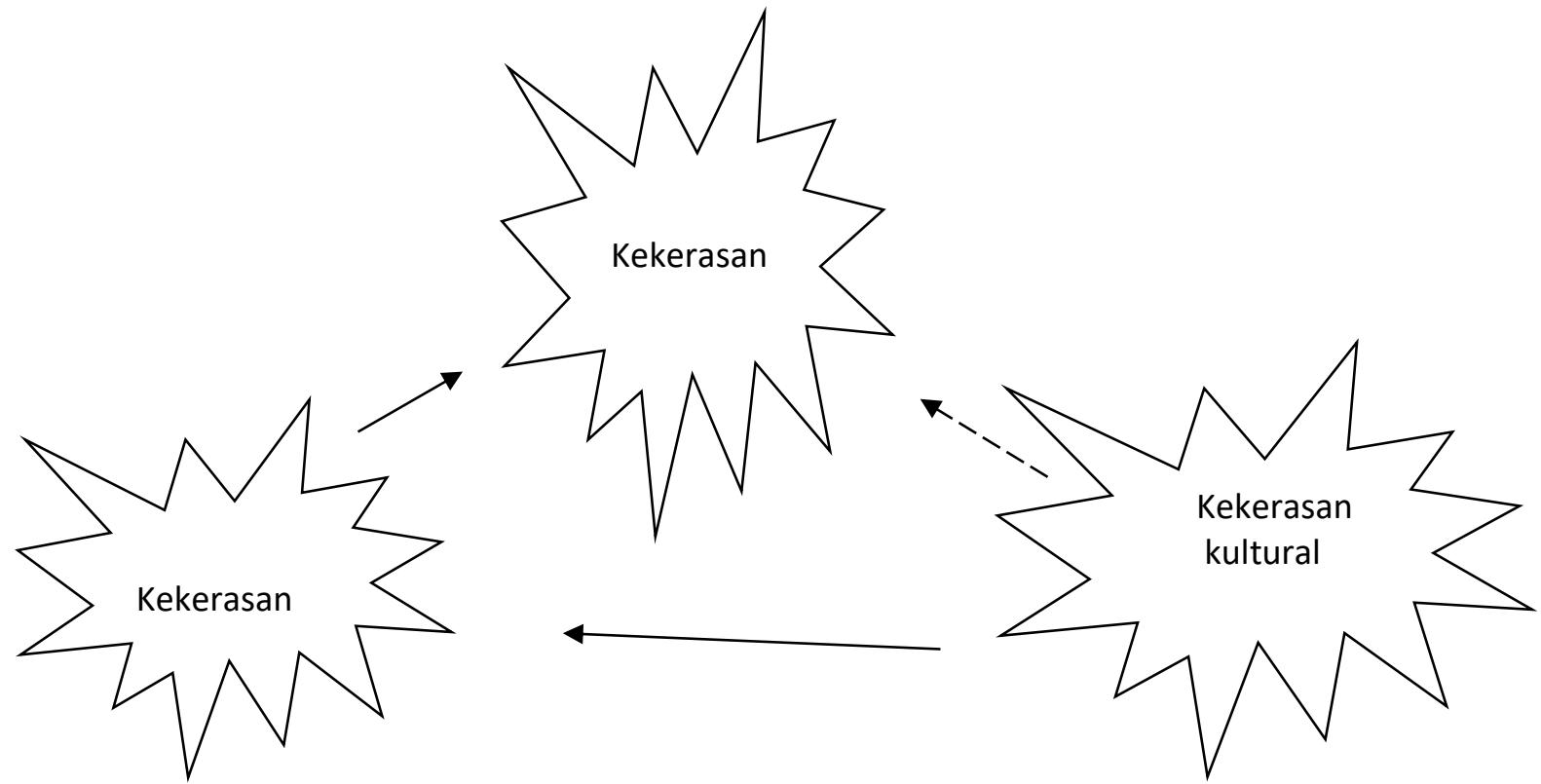

38. Diterjemahkan oleh Slamet Raharjo.

27 Johan Galtung, Kekerasan Budaya dalam Haqqul Yakin. Agama dan Kekerasan dalam Transisi Demokrasi di Indonesia. (Yogyakarta: elSAQ Press, 2009). Hlm 45-46. 


\section{Dalam pandangan Galtung:}

Karena kekerasan kultural merupakan sumber terjadinya jenis kekerasan lainnya, maka untuk memerangi atau menghilangkan kekerasan struktural (ketidakadilan dan diskriminasi) dan kekerasan langsung (pembunuhan maka budaya harus menjadi agenda utama. Selain itu, untuk menghindari atau menghentikan tindak kekerasan membutuhkan sebuah proses transformasi sosio-kultural dalam sebuah masyarakat. Jika kekerasan struktural dan kekerasan langsung dibiarkan terjadi karena adanya kekerasan kultural, maka untuk menghentikan kekerasan langsung dan kekerasan struktural dibutuhkan sebuah transformasi yang menggantikan kekerasan kultural menjadi perdamaian kultural dan budaya non kekerasan. ${ }^{28}$

Sehubungan dengan transformasi dimaksud, Chaiwat menyatakan bahwa

kekerasan kultural akan berlangsung lama karena perubahan-perubahan budaya akan

berjalan lambat. Mengenai proses terjadinya konflik kekerasan kultural akan berlangsung lama karena perubahan-perubahan budaya akan berjalan lamban. ${ }^{29}$

Mengenai proses terjadinya konflik kekerasan, Galtung menyatakan:

Kekerasan kultural menyebabkan langsung kekerasan struktural dan kekerasan langsung biasanya melalui proses yang lebih panjang yakni berawal dari kekerasan kultural mengakibatkan kekerasan struktural baru menuju ke kekerasan langsung. Dalam kenyataannya, proses semacam ini memang lebih sering terjadi. Mereka yang melakukan kekerasan langsung sebenarnya mencoba mencari penyelesaian atas ketidakadilan yang dirasakannya dalam bidang ekonomi, budaya, sosial dan politik. Mereka meyakini bahwa kondisi ketidakadilan itu telah merusak kehidupannya. Dengan melakukan kekerasan langsung mereka berharap dapat merombak seluruh tata sosial ekonomi yang tidak adil tersebut.

Selanjutnya Galtung mengemukakan:

Bahwa kekerasan langsung sebagai peristiwa di puncak strata dan karena itu gampang terlihat. Berikutnya adalah pola-pola perubahan eksploitasi dengan mekanisme yang dibutuhkannya baik dalam mencegah pembentukan kesadaran maupun menghambat pengorganisasian terhadap eksploitasi dan penindasan. Inilah strata kekerasan struktural yang dilihat sebagai proses perubahan. Ia tidak begitu terlihat dan karenanya lebih berbahaya. Strata dasar

28 Ibid. hlm 52-53

29 Chaiwat S. Anand. Agama dan Budaya Perdamaian (Yogyakarta: Fk BA dan QIA UGM, 2002) hlm 113. 


\section{ART IKEL}

adalah yang tetap mengalir sepanjang masa yakni kekerasan struktural, yang menopang kedua strata di atas. ${ }^{30}$

Berdasarkan pemikiran Galtung itu dapat disimpulkan bahwa konflik kekerasan terjadi disebabkan oleh adanya kekerasan struktural yang disyahkan (dilegitimasi) oleh kekerasan struktural di dalam masyarakat. Jadi fondasi dasarnya adalah pada kekerasan kultural.

Teori kekerasan Galtung ini tepat untuk menganalisis kekerasan budaya yang berbasis agama. Kekerasan agama secara struktural sering bermula dari pemahaman dari para pemeluknya sehingga muncul tafsir-tafsir yang berbeda dengan kelompokkelompok keagamaan lainnya.

Analisis mazhab multidisipliner yang lain adalah menggunakan pendekatan primordial yang dikemukkan oleh Giddens. Menurut Giddens persoalan konflik dalam masyarakat juga mendapatkan perhatian dari para pengamat entitas dan ras sebagai suatu kelompok identitas dan kepentingan mereka dalam struktur sosial. Analisis ini disebut dengan pendekatan primordial yang melihat konflik sebagai akibat dari pergesekan kelompok identitas, seperti identitas yang berbasis etnik dan agama. Teori ini memahami konflik sebagai akibat pertemuan dari berbagai budaya, ras, agama, dalam suatu georgafis yang melahirkan suatu identitas dan rasa solidaritas. Pendekatan ini berpandangan bahwa konflik adalah di semua level masyarakat dan negara di mana orang-orang terbagi kemjadi kelompok-kelompok terpisah berbasis ras, etnik, bahasa, agama, kasta, dan lainnya. Aliran ini menolak teori yang berpandangan bahwa

30 Yohanes Bahari. Op.cit. hlm 53 


\section{ART IKEL}

perkembangan masyarakat ke arah modern akan menghapus bentuk-bentuk kesadaran primordial. $^{31}$

\section{KESIMPULAN}

Teori konflik muncul seiring dengan munculnya sosiologi. Dilihat dari segi historis, teori konflik terbagi dua, teori konflik klasik dan kontemporer. Teori konflik kontemporer merupakan penyempurnaan dari teori konflik klasik yang memandang konflik sebagai sesuatu yang melekat dalam setiap tingkatan masyarakat. Faktor penyebab konflik tidak lagi determinasi ekonomi, namun juga disebabkan faktor lain, seperti kekuasaan dan prestise. Konflik tidak hanya dipandang sesuatu yang destruktif tetapi juga dapat berfungsi konstruktif bagi masyarakat.

Ada empat mazhab teori konflik. Pertama mazhab positivis yang ditokohi oleh Ralph Dahrendorf dan Lewis Coser. Mazhab ini memandang konflik struktural yang disebabkan oleh kekuasaan dan analisis fungsi konflik bagi masyarakat. Mazhab humanis yang ditokohi oleh Herbert Blumer dan Peter Berger. Mazhab ini memandang konflik dengan menggunakan analisis interaksi simbolik untuk melihat berbagai fenomena konflik pada skala mikro dan lingkungan yang lebih spesifik. Simbol bisa dimaknai secara variatif oleh masing-masing aktor dalam interaksi sosial. Makna negatif dalam bentuk kebencian akan mengakibatkan prasangka (prejudice) dan tindakan permusuhan (bostile feeling). Teori lainnya dalam mazhab humanisme adalah teori konstruksi sosial konflik. Teori ini dikembangkan oleh Peter L. Berger dan Luckman. Konstruksi sosial merupakan kajian yang berkembang dari sosiologi pengetahuan yang

31 Anthony Giddens. Human Societies A Reader. (Cambridge: Polity Press, 1992) dalam Novri Susan hlm 84-85 
melihat konflik sebagai manifestasi sosial dari dialektika sosial. Ketiga mazhab kritis yang ditokohi oleh Bourdieu dan Jurgen Habermas. Mazhab ini berusaha menganalisis emansipasi yang berusaha membebaskan masyarakat dari kekejaman struktur sosial yang menindas masyarakat oleh sekelompok penguasa. Terahir, mazhab multidisipliner yang ditokohi oleh Johan Galtung dan Anthony Giddens. Mereka menganalisis konflik tidak hanya menggunakan satu teori atau pendekatan, tetapi menggunakan berbagai macam teori atau disiplin ilmu berdasarkan kebutuhan analisis, seperti trancend approach oleh Galtung dan pendekatan primordial oleh Giddens. Semuanya mazhab di atas memberikan pemahaman kepada kita yang lebih komprehensif tentang konfik-konflik yang terjadi di masyarakat.

\section{DAFTAR PUSTAKA}

Anand, Chaiwat S. Agama dan Budaya Perdamaian (Yogyakarta: Fk BA dan QIA UGM, 2002).

Bahari, Yohanes. Resolusi Konflik Berbasis Pranata Adat Pamakang dan Pati Nyawa pada Masyarakat Dayak Kanayatn di Kalimantan Barat (Bandung, Program PPS Unpad, 2005).

Coser, Lewis. The function of social conflict. (New York: Free Press, 1956).

Craib, Ian. Teori-Teori Sosial Modern dari Parsons sampai Habermas (Jakarta: Raja Grafindo Persada, 1994). Cetakan ke-3. Diterjemahkan oleh Paul S. Bault dan T. Effendi. Dahrendorf, Ralf. Class and Class Conflict in Industrial Society (California: Stanford University Press, 1959). 


\section{ART IKEL}

Galtung, Johan Peace by Peaceful Means: Peace and conflict Development and civilization.(London: IPRIO, 1996).

Giddens, Anthony . Human Societies A Reader. (Cambridge: Polity Press, 1992).

Habermas, Jurgen. On The Pragmatics of Communication. (Massachusetts: The MIT Press, 1998).

Kinloch, Graham C. Perkembangan dan Paradigma Utama Teori Sosiologi. (Bandung: Pustaka Setia, 2005). Cetakan Pertama. Editor: Dadang Kahmad. Diterjemahkan dari Sociological Theory: Its Development and Major Paradigm.

Nasikun. Sistem Sosial Indonesia. (Jakarta: CV Rajawali, 1992). Cetakan ketujuh.

Poloma, Margaret M. Sosiologi Kontemporer. (Jakarta: Raja Grafindo Persada, 2003). Cetakan ke-5. Diterjemahkan oleh tim penerjemah Yosogama dari judul asli Contemporary Socilogical Theory.

Rahman, M. Taufiq. Glosari Teori Sosial, (Bandung: Ibnu Sina Press, 2011).

Rahman, M. Taufiq. Pengantar Filsafat Sosial, (Bandung: Lekkas, 2018).

Ritzer, George dan Douglas J. Goodman. Teori Sosial Modern .(Jakarta: Kencana, 2004) Edisi pertama. Diterjemahkan oleh Alimandan dari buku aslinya Modern Sociological Theory, Sixth Edition.

Ritzer, George. Sociological Theory. (Singapore: McGraw-Hill, 1992) Third Edition.

Saifuddin, Ahmad Fedyani. Konflik dan Integrasi: Perbedaan Faham dalam Agama Islam. (Jakarta: Rajawali, 1986).

Salmi, Jamil. Violence and Democratic Society: Hooligansime dan Masyarakat Demokrasi. (Yogyakarta: 2005, Nuansa Aksara). Diterjemahkan oleh Slamet Raharjo.

Santoso, Thomas (ed) Teori-Teori Kekerasan (Jakarta: Ghalia, 2002). 
ART IKEL

E-ISSN: 2615-5028

Sunarta. Integrasi dan Konflik: Kedudukan Politik Jawara dan Ulama dalam Budaya Politik Lokal (Bandung: PPS Unpad Bandung, 1997) Disertasi.

Susan, Novri. Sosiologi Konflik: Isu-isu konflik kontemporer. (Jakarta: Kencana, 2009). Cetakan pertama.

Wallace, Ruth A. and Alison Wolf. Reading in Contemporary Sociological Theory from Modernity to Post Modernity. (New Jersey: Prentice Hall. 1995).

Yakin, Haqqul. Agama dan Kekerasan dalam Transisi Demokrasi di Indonesia. (Yogyakarta: elSAQ Press, 2009). 